\title{
An Investigation and Analysis of Teacher Talk in College English
}

\section{Class}

\author{
Min Liu ${ }^{1} \&$ Lei Zhu ${ }^{1}$ \\ ${ }^{1}$ School of Foreign languages, University of Jinan, Jinan, China \\ Correspondence: Min Liu, School of Foreign languages, University of Jinan, Jinan 250022, Shandong, China. Tel: \\ 86-531-8276-5481.E-mail: sfl_lium@ujn.edu.cn
}

Received: August 4, 2012

Accepted: August 23, 2012 Online Published: September 26, 2012

doi:10.5539/ijel.v2n5p117

URL: http://dx.doi.org/10.5539/ijel.v2n5p117

\begin{abstract}
Teacher talk is the major resources of comprehensible target language input learners are likely to receive in the foreign language classroom teaching. The current study, based on class videotapes of four college English teachers and questionnaires, attempted to investigate and analyze the phenomenon of teacher talk time, questioning pattern, and feedback pattern. The findings showed that although communicative approach and classroom interaction are highly advocated and adopted, one-way communication still dominants class teaching and learning in college English classroom in University of Jinan, class activities are still lack of real communication information. Efforts should be made in the future to enhance teachers' awareness in this respect and relevant training and evaluation should also be organized.
\end{abstract}

Keywords: teacher talk, questioning pattern, feedback

\section{Introduction}

Teacher talk refers to the language used by the teacher when addressing L2 learners in classroom interaction (Ur, 2000). Teacher talk is of crucial importance, not only for organization and management of the classroom but also for the processes of acquisition (Nunan, 1991). Whether a class is successful or not depends to a large degree on the effectiveness of teacher talk (Hakansson, 1986).

In traditional teacher-centred English class, Teachers only think of passing on the knowledge, efficient communication between teachers and students are rare. Currently, student-centred method and interaction teaching mode dominants class teaching and learning. Teacher is regarded as an important part of teaching environment and teacher's language is the main sources of information, especially in English class in China, teacher talk is the major or only English input. The teacher is a guide and assessor and appropriate forms of teacher talk can create an ideal English environment for students to learn and communicate in the target language, which will help students acquire a good language habit and linguistic competence (Anton, 1993).

In the past few decades, many quantitative studies have been conducted involving teacher talk, and much attention were paid to the content of it , such as the rates of speed, pause, vocabulary use, pronunciation, degree of subordination, ect. (Chaudron, 1998). Pica and Long (1986) has observed ten teachers who used one-way communication to convey information to students. They found that more declaratives and statements are used than questions, display questions and comprehension checks are more used than referential questions and clarification requests. Thus they drew a conclusion that teacher-centred class are lack of real communicative information. And Brock (1986) found referential question help students assimilate more meaningful outputs, which will eventually improve their language acquisition. In china, studies of the language teacher use in class include those of Zhao (1998), Zhou, X. and Zhou, Y. (2002), Hu (2004), etc. They observed some kinds of phenomenon about teacher talk, such as the quantity of teach talk, the adjustments, teacher questions and teach feedback. But compared with teacher talk research overseas, relatively few articles have been written concerning some aspects of teach talk in China. Since it is important for English teaching practice and studies of pedagogy, a systematic study of teacher talk in China is needed.

\section{Research Design}

\subsection{Research Questions}

The present study attempted to investigate teacher talk pattern in college English class based on student-centred 
teaching and learning. It was intended to analyze the following phenomenon of teacher talk: (1) teacher talk time; (2) questioning pattern; (3) feedback pattern.

\subsection{Research Method}

Naturalistic inquiry was adopted to investigate teach talk in classroom interaction. We randomly selected four college English teachers in University of Jinan (UJN), and videotaped their English class (45 minutes) respectively. The videotapes were then transcribed by the researchers for further statistic analysis. Questionnaire designed by Zhou, X. and Zhou, Y. (2002) was used to evaluate class teaching and learning and teacher talk. A total of 216 second-year college students in UJN were randomly selected to complete the questionnaires. In April, 2011, the questionnaires were distributed to students in regular class time with the help of their English teacher. Students were given 10 minutes to finish it. Samples were narrowed down to 209 after a preliminary check of the questionnaires.

\section{Results and Analysis}

\subsection{Teacher Talk Time}

Based on classroom videotapes, the researchers analyzed the proportion of teacher talk and students talk time in a regular English class (45 minutes), as shown in Table 1.

Table 1. The proportion of teacher and student talk time

\begin{tabular}{lcccccc}
\hline \multirow{2}{*}{ Class } & \multicolumn{2}{c}{ Teacher talk } & \multicolumn{2}{c}{ Student talk } & \multicolumn{2}{c}{ Other activities } \\
& $\mathrm{t}(\mathrm{min})$. & $\%$ & $\mathrm{t}($ min.) & $\%$ & $\mathrm{t}(\mathrm{min})$. & $\%$ \\
\hline Class 1 & 26 & $58 \%$ & 14 & $31 \%$ & 5 & $11 \%$ \\
Class 2 & 19 & $42 \%$ & 19 & $42 \%$ & 7 & $16 \%$ \\
Class 3 & 21 & $47 \%$ & 19 & $42 \%$ & 5 & $11 \%$ \\
Class 4 & 16 & $36 \%$ & 25 & $56 \%$ & 4 & $8 \%$ \\
\hline
\end{tabular}

As Table 1 indicated, teacher talk time dominants most of the class time, vary from $36 \%$ to $58 \%$, and student talk time is less, which is coincide with the questionnaires, $67 \%$ respondents thought that their teacher speaks more than 20 minutes per class. Though it is lower than the findings of Pica and Long (1986), and Zhao (1998), in their study of teacher-cantered English class, nearly $70 \%$ talk time was occupied by teachers. The results is different from Zhou, X. and Zhou, Y. (2002), they found in student-centred classroom interaction, student talk time is more than half of the class time. A possible reason is that although student-centred teaching method and classroom interaction are advocated, many teachers still aimed at imparting knowledge to students, but not training them to acquire skills of understanding others and express themselves by means of communication.

Too much teacher talk is not an ideal method for teaching, because language is a means of communication. Two-way communication, which can promote meaning negotiation and interactional modification between speakers, is better than one-way communication. Students learn English as a communicative tool, not as a system of linguistic knowledge. They would not be able to speak or write English merely by attending lectures. The best efficiency in teaching English probably comes from an effective cooperation between teachers and students. Students should be given more time to practice communicating in English, only in this way, students can leap from the stage of "knowing English" to the stage of "using English". So, student talk time is of great importance for students to learn English and to use it properly. As Richard (1996) had mentioned, "getting students to speak - to use the language they are learning-is a vital part of a teacher's job”. Therefore, an appropriate ratio of time between teacher and student are beneficial for both sides.

\subsection{Questioning Patterns}

Teacher questions have been traditionally viewed as an important constituent of teacher talk in classroom context. And questioning pattern has received much attention (Nunan, 1991). Questions and answers is widely used in English teaching, through which teachers can help students adjust their language and make it more comprehensible (Harmer, 2000). Teacher questions in class can be divided into two categories: display questions and referential questions. The former refers to the question that the questioner has already known the answer, while the latter refers to those open ended questions. Recent survey showed that the purpose of display question was for the sake of practicing structures, so language in these activities is lack of real communication 
information. As Richards and Lockhart (1996) had indicated, Teacher talk emphasizes the production of correct grammatical forms, and they are not really interested in what the learners have to say. Many researchers mentioned that to stimulate students' interest and enthusiasm, more referential questions should be asked in English class.

Table 2. The proportion of display questions and referential question

\begin{tabular}{lccccc}
\hline Class & Total number of questions (n) & \multicolumn{2}{c}{ Display questions } & \multicolumn{2}{c}{ Referential questions } \\
& $\mathrm{n}$ & $\mathrm{n}$ & $\%$ & $\mathrm{n}$ & $\%$ \\
\hline Class 1 & 21 & 15 & $71 \%$ & 6 & $29 \%$ \\
Class 2 & 13 & 10 & $78 \%$ & 3 & $21 \%$ \\
Class 3 & 19 & 13 & $68 \%$ & 6 & $32 \%$ \\
Class 4 & 28 & 21 & $75 \%$ & 7 & $25 \%$ \\
Sum & 81 & 59 & $73 \%$ & 22 & $27 \%$ \\
\hline
\end{tabular}

As is shown in Table 2, display questions (73\%) are asked more than referential questions (27\%) in English class in UJN, which is similar to results of questionnaires, $63 \%$ respondents thought that most of the questions asked in class are display questions. The result is similar to Long and Sato (1983). In their study, $79 \%$ questions are display questions. They explained it as the predominance of one-way communication in classroom. In UJN, even we advocate communicative approach and classroom interaction. The findings are not so satisfying. Maybe some factors affecting teachers' questions, for example, students' linguistic competence, teacher's belief, and even size of classes. In UJN, the number of students range from 60 to nearly 100 in English class, the more students a class contains, the more difficult it is for the teacher to control teaching and learning activities.

After a question is asked, traditionally, there is a "wait time" for students to think and respond. "Wait time" is also a very important part of teacher talk. How long the teacher waits after asking a question determines to some extent how well students make a response. After teacher asks a question, the students needs adequate "wait time" to think over the question before attempting to answer it. Study showed that in classroom where teacher tried to wait for three to five seconds after asking a question, there was more participation by more students. Therefore, the appropriate "wait time" will make a great difference for a successful English class.

Another phenomenon we should attach importance to is comprehensible input in teacher talk. According to Krashen's hypothesis of comprehensible input (i+1), teacher talk, as one kind of input, should be slightly beyond the learner's current knowledge level (Krashen, 1985). Input should be rich and comprehensible. Teacher talk, as one kind of input, should be slightly beyond the learner's current knowledge level. If the input is too simple for students in class, then they will think it meaningless and boring .If the input is difficult for them to follow, they will lose learning enthusiasm. Gradually, they will become lazy and their minds will accept nothing but simplified input. Progress is out of question. Besides, Input should also be interesting and relevant (Wedell, 1996). Teacher talk, basically, is to arouse students' potential natural learning ability which is hidden in their mind. Teacher should try to update their knowledge and belief, follow the pace of the modern society. Facial expressions, Humorous speech, up-to-date information and innovative teaching methods and so on can be used to attract students Therefore, "language directed to the learners that contains some new element in it but this is nevertheless understood by the learner because of linguistic, paralinguistic, or situational cues, or world knowledge backup" (Swain, 1993). Nunan's explanation is also consistent with Krashen's (i+1) input hypothesis, he suggested that teachers should provide more elaborated input. That is to say, they should try to build in redundancy through the use of repetition, paraphrase and rhetorical makers.

\subsection{Feedback Pattern}

Another important constituent of teacher talk is feedback. Typical interaction in the classroom follows a very rigid pattern: Teacher initiates, student responds, and the teacher provide feedback to the learner. A considerable amounts of researches indicated that positive feedback can not only let the learners know that they successfully finish their learning task, but also stimulate their learning interests and motives. Thus, positive feedback is better than negative feedback in the progress of promoting learner's learning behavior (Nunan, 1991). 
Table 3. The proportion of different kinds of feedback

\begin{tabular}{lccccccccccc}
\hline Class & $\begin{array}{c}\text { Total } \\
\text { feedback (n) }\end{array}$ & \multicolumn{2}{c}{ Praise } & \multicolumn{2}{c}{ Praise with } & \multicolumn{2}{c}{ Repetition } & \multicolumn{2}{c}{ Ask another } & \multicolumn{2}{c}{ Guide to } \\
& $\mathrm{n}$ & $\mathrm{n}$ & $\%$ & $\mathrm{n}$ & $\%$ & $\mathrm{n}$ & $\%$ & $\mathrm{n}$ & $\%$ & $\mathrm{n}$ & $\%$ \\
\hline Class 1 & 21 & 5 & $24 \%$ & 10 & $48 \%$ & 2 & $9 \%$ & 0 & 0 & 4 & $19 \%$ \\
Class 2 & 13 & 6 & $46 \%$ & 2 & $15 \%$ & 3 & $23 \%$ & 0 & 0 & 2 & $15 \%$ \\
Class 3 & 19 & 3 & $16 \%$ & 9 & $47 \%$ & 4 & $21 \%$ & 1 & $5 \%$ & 2 & $11 \%$ \\
Class 4 & 28 & 4 & $14 \%$ & 7 & $25 \%$ & 11 & $39 \%$ & 3 & $11 \%$ & 3 & $11 \%$ \\
\hline
\end{tabular}

As indicated in Table 3, nearly 70\% feedback was positive and effective feedback, such as praise with comments, repetition plus praise and guide to self-repair, which is of great significance for language learner to stimulate their learning motives and enthusiasm. But one thing that should be made clear is that too general and automatic positive feedback, such as "good" and "very good", seems have no effect on positive learning behavior. Another phenomenon worth mentioning is ungrammatically speech modification, nearly $70 \%$ respondents chose “don't interrupt me to correct my mistake while I'm speaking". This phenomenon indicted that teacher should correct mistake properly. Anyone, even he is a native speaker, will definitely make mistake, grammatically or syntactically. Teachers could not be too strict to students' mistake if they don't affect communication. Besides, Teachers should distribute questions and praises fairly and avoid favoring a particular group of students. If a teacher shows favor to some students, others may feel excluded and ignored by the teacher. They won't be co-operative with the teacher, and this is very harmful to the homonymous atmosphere of the ELT.

\section{Conclusion}

The present study investigated teacher talk pattern in college English class in UJN. The findings showed that although communicative approach and classroom interaction are highly advocated, one-way communication still dominants class teaching and learning, class activities are lack of real communication information, and the real meaning negotiation can't be achieved successfully. An appropriate ratio of time between teacher and student are beneficial for both sides. Efforts should be made to enhance teachers' awareness in this respect and relevant training and evaluation should also be organized. The best efficiency in teaching English probably comes from an effective cooperation between teachers and students

\section{References}

Anton, M. (1999). The discourse of a learner-cantered classroom: Sociocultural perspectives on teacher-learner interaction in the second language classroom. The Modern language Journal, 83, 303-318. http://dx.doi.org/10.1111/0026-7902.00024

Brock, C. (1986). The effects of referential question on ESL classroom discourse. TESOL Quarterly, 20(1), 47-59. http://dx.doi.org/10.2307/3586388

Chaudron, C. (1988). Second Language Classrooms: Research on Teaching and Learning. Cambridge: Cambridge University Press.

Hakansson, G. (1986). Quantative studies of teacher talk. In Kasper (Ed.), Learning, Teaching and Communication in the Foreign Language Classroom. Aarhus: Aarhus University Press.

Harmer, J. (2000). How to teach English. Beijing: Foreign Language Teaching and Research Press.

Hu, Q. Q., Nicholson, E., \& Chen, W. (2004). An investigation and analysis of questioning pattern of college English teacher. Foreign Language World, 6, 22-27.

Krashen, S. (1985). The Input Hypothesis: Issues and Implication. London: Longman.

Long, M. H., \& Sato, C. J. (1983). Classroom foreigner talk discourse: Forms and functions of teachers questions. In Seliger, H. W., \& Long, M. H. (Eds.), Classroom Oriented Research in Second Language Acquisition. Rowley, Mass: Newbury House.

Nunan, D. (1991). Language Teaching Methodology: A Text book for Teachers. Englewood Cliffs, NJ: Prentice Hall Inc. 
Pica, T., \& Long, M. H. (1986). The linguistic and conversational performance of experienced and inexperienced teachers. In Day, R. R. (Ed.), Talking to learn: Conversation in second language acquisition (pp. 85-98). Rowley, Mass: Newbury House.

Richards, J., \& Lockhart, C. (1996). Reflective Teaching in Second language Classrooms. Cambridge: Cambridge University Press.

Swain, M. (1993). The output hypothesis: Just speaking and writing aren't enough. The Canadian Modern Language Review, 50, 53-74.

Ur, P. (2000). A Course in Language Teaching: Practice and Theory. Beijing: Foreign Language Teaching and Research Press.

Wedell, M. (1996). Language Teaching and Learning — from theory to practice. Beijing: Higher Education Press.

Zhao, X. H. (1998). An investigation and Analysis of Teacher Talk of college English teacher in Reading Class. Foreign Language World, 2, 17-22.

Zhou, X., \& Zhou, Y. (2002). An investigation and analysis of teacher talk of college English teacher. Foreign Language Teaching and Research, 1, 59-68. 